\title{
КОРАБЛЕБУДУВАННЯ
}

УДК 520.6.05

DOI https://doi.org/10.32838/TNU-2663-5941/2020.6-2/05

\section{Коваленко I.В.}

Азовський морський інститут

Національного університету «Одеська морська академія»

\section{ШЛЯХИ ПШДВИЩЕННЯ ТЕХНОЛОГІЧНОЇ НАДІЙНОСТІ СУДНОВИХ ЕНЕРГЕТИЧНИХ УСТАНОВОК ІЗ ЗАСТОСУВАННЯМ РІЗНОРІДНИХ СТАЛЕЙ}

На сучасному етапі розвитку кораблебудування у світі та Україні приділяється увага до використання економно легованих конструкційних матеріалів, які мають стабільні експлуатаційні властивості. При розробиі нових технологій, застосовуваних у виготовленні суднових допоміжних механізмів, дуже важливо дослідити властивості з'єднань різнорідних сталей і утворену ними виражену хімічну, структурну і механічну неоднорідність. При проведенні аналізу цих факторів повинні враховуватися як властивості та призначення матеріалів конструкиї, так і вибір технології ї̈ виготовлення.

Застосовувані при розробиі иієї технології методи зварювання повинні забезпечувати мінімізацію витрат і оптимізацію геометрії зварного шва. Також важливим фактором є оиінка ступеня легування марок зварювальних сталей і рівень сумарної собівартості виготовлення виробу. Дослідження властивостей перехідних шарів шва й основного металу і їх вплив на кількість ииклів навантаження при випробуваннях також є ключовими. Тому мінімізачія числа дифузійних прошарків у зоні сплаву знижують ииклічну втому металу шва і є основним фактором.

Важсливим є порівняння зварних з'єднань різного ступеня і класу легування. Наприклад, порівняння термічно зміцненої та дисперсно твердих аустенітних сталей. Для сталей иъьго класу термічна обробка після зварювання є обов'язковою для відновлення властивостей навколошовної зони. Також важливою є підсумкова структура шва, яка безпосередньо визначає число ииклів до початку першого етапу руйнування. Найкращі властивості з погляду експлуатації у дрібнодисперсної аустенитної та перлітної структур. Особлива роль належить вибору режимів термічної обробки зварного з'єднання, вона залежсить від рівня легування $\mathrm{Ni}, \mathrm{Mg}, \mathrm{Cr}$ як основного металу, так і зварного з'єднання. Також необхідно розглянути і величини експлуатаційних навантажень на суднові енергетичні установки.

Ключові слова: легуючі елементи, аустеніт, основний метал, наплавлений метал, перехідний шар, структура металу.

Постановка проблеми. Різнорідні сталі є універсальним матеріалом, який застосовується в багатьох секторах світової економіки: металургії, машинобудуванні, енергетиці, будівництві, оборонному комплексі, кораблебудуванні.

Також різнорідні сталі є високотехнологічним матеріалом, що сприяє підвищенню ефективності виробництва, енергоефективності, матеріалоефективності, періоду і циклу експлуатації та рівня якості.

У світовій практиці при використанні різнорідних сталей для виготовлення конструкцій найбільш поширені поєднання основного шару 3 конструкційної сталі, а робочого шару - 3 низьколегованої матеріалу, у якого підвищені експлуатаційні властивості.
Найбільш раціональним є використання різнорідних сталей як основного матеріалу при виготовленні вузлів суднових агрегатів. Такий вид конструкційного матеріалу найбільш стійкий до впливу як циклічних деформацій, так і агресивних середовищ. У багатьох джерелах представлений досвід застосування різнорідних сталей як основного матеріалу суднових металоконструкцій. Вибір різнорідної сталі, що складається із шару конструкційного матеріалу і легованого шару, мало висвітлений у наукових джерелах. Не повною мірою розкрито методи підбору класу сталі, ступеня легування і типу термічної обробки. Недостатньо описані процеси взаємодії легуючих елементів із перехідним шаром.

Тому питання отримання якісних зварних з'єднань у суднових металоконструкціях 
із двошарових сталей, здатних тривалий час сприймати статичні навантаження і працювати за підвищених температур і агресивних середовищ, $\epsilon$ досить актуальним.

Дослідження в цьому напрямі важливі для багатьох компаній і підприємств, які спеціалізуються на ремонті та виготовленні елементів суднового енергетичного устаткування. Результати, наведені в цій статті, допоможуть зменшити змінну частину собівартості виготовлення і ремонту суднового устаткування.

Аналіз останніх досліджень і публікацій. При розгляді технології виготовлення вузлів суднових конструкцій із різнорідних сталей різними методами зварювання основною вимогою вибору зварювального режиму є забезпечення заданого співвідношення проплавлення кожної зі зварювальних кромок, але важливим залишається пошук технологічного підходу до зварювання плавленням із вимогою відомості до мінімуму частки основного металу у шві. Цей результат досягається процесом на режимах із мінімальною силою струму за помірних швидкостей.

Відомо, що способи зварювання плавленням, формування шва в яких йде тільки за рахунок проплавлення основного металу, впливають на властивості шва [1]. Причиною цього можуть бути грубозернисті структури, схильні до охрупчення. Вирішення цього питання полягає у використанні автоматичного зварювання під флюсом при приварці шипів зі сталі типу сіхромаль до труб із маловуглецевої сталі до поверхні нагрівання котлів [2]. Такий підхід дозволяє стверджувати, що у швах за рахунок проплавлення матеріалу дроту утворюється однофазна феритна структура, і вони стають крихкими після експлуатації за інтервалу температур $400-500^{\circ} \mathrm{C}$. Стійкість швів проти охрупчення не була помітно підвищена, коли перед зварюванням була введена операція нікелювання зварної ванни [3]. Тому важливий пошук конструкційних матеріалів, у яких нікель переходив у шов, тому додатково легують його, що призводить до усунення однофазної великої феритної структури.

Актуальним залишається питання вибору зварювальних матеріалів. Від легування наплавленого металу істотно залежить можливість утворення в перехідних шарах шва тендітних структур і тріщин, а також інтенсивність розвитку в зоні сплаву кристалізаційних і дифузних шарів. У комбінованих суднових конструкціях метал шва за своєю міцністю може задовольняти вимоги менш міцною зі сталей. Зазвичай зварні шви за механічними властивостями в жароміцних сталях близькі або навіть перевершують властивості основного металу [4]. Тому використання зварювальних матеріалів близького складу, але менших за міцністю і з менш легованими складами задовольняе вимоги, що висуваються до міцності суднових конструкцій. Помітно спрощується технологія зварювання таких виробів і підвищується їх експлуатаційна міцність [5].

Тому необхідно виконати та сформулювати обгрунтування вибору основного металу та зварювальних матеріалів для виготовлення суднових конструкцій. Найбільш необхідне обгрунтування вибору матеріалів у з'єднаннях різнорідних перлітових і високохромистих сталей. Однак при зварюванні перлітових сталей 3 аустенітними існує небезпека утворення загартованих структур і тріщин у ділянках шва, що примикають до аустенітної сталі [6], тому необхідно застосувати високолеговані зварювальні матеріали, які мають різну структуру після кристалізацій.

Все це дає підстави стверджувати, що проведення аналізу та дослідження в цьому напрямі $\epsilon$ актуальними.

Постановка завдання. Основним завданням дослідження $\epsilon$ аналіз та обгрунтування забезпечення правильного підбору основного металу i зварювальних матеріалів у виготовленні суднових енергетичних установок вузлів із різнорідних сталей. Також необхідно обгрунтувати супутні режими термічної обробки.

Для досягнення поставленої мети необхідно виконати такі завдання:

- обгрунтувати вибір матеріалу і режиму термічної обробки з урахуванням основних і додаткових вимог вибору зварювального режиму щодо забезпечення заданого співвідношення проплавлення кожної зі зварювальних кромок, без виникнення мартенситних структур;

- структурувати вимоги до аустенітного матеріалу, суднових конструкцій із різними геометричними параметрами при стиковому зварюванні при переході від м'яких до жорстких режимів;

- визначити вплив легуючих елементів за різних методів зварювання плавленням на частку основного металу у шві за рахунок ведення процесу на режимах із мінімальною силою струму за помірних швидкостей.

Виклад основного матеріалу дослідження. При дослідженні процесу вибору матеріалів для зварювання перлітових сталей доцільно використовувати зварювальні матеріали, близькі за складом до менш легованої сталі [7]. Оскільки технологічна міцність перлітових швів знижується 
із підвищенням ступеня їх легування, необхідно забезпечити відсутність у швах тріщин за рахунок пропорції елементів. У зварних з'єднаннях високохромистих мартенситних, феритних і феритоаустенітних сталей, вибір електродних матеріалів для зварних з'єднань різнорідних високохромистих сталей визначаються рядом вимог. Найголовніша 3 них - отримання швів без тріщин і відсутність у них тендітних складників [8]. При зварюванні цих сталей внаслідок високого вмісту в основному металі енергійного карбідоутворюючого елемента - хрому - помітного розвитку дифузних шарів у зоні сплаву очікувати не слід. Дослідження зварювання 12-відсоткових хромистих мартенситних або мартенситно-феритних сталей різного легування показало, що для цього виду зварювання можуть застосовуватися електродні матеріали 3 легуванням хромом не менше 10\% для будь-якої зі зварювальних сталей. При автоматичному зварюванні під флюсом сталей цього класу або у вуглекислому газі необхідно використовувати зварювальний дріт типу 08Х14ГТ, який забезпечує високу циклічну стійкість до тріщин металу шва.

Режим підігріву для сталей вищевказаних класів слід вибирати за вимогами сталі, яка має найбільшу схильність до загартовування і зазвичай підвищений вміст вуглецю. Його температура залежно від жорсткості конструкції та вмісту у сталі вуглецю може коливатися в межах $200-400^{\circ} \mathrm{C}$ [9]. Після зварювання обов'язковим $\epsilon$ термічний відпуск за температури $700-750^{\circ} \mathrm{C}$. Якщо товщина зварювальних елементів перевищує 30 мм, то до охолодження конструкції не нижче температури $100-150^{\circ} \mathrm{C}$ необхідно поміщати iї в термічну піч для нагрівання під відпуск.

Дослідження зварювання 12-відсоткових хромистих мартенситних сталей із високохромистими феритними та ферито-аустенітними сталями показали, що найбільш доцільно використовувати зварювальні матеріали ферито-аустенітного класу. Перевагою цих матеріалів порівняно з феритними (типу ЕФХ17) є мала схильність металу шва до зростання зерна і висока його пластичність у початковому стані після зварювання (рис. 1).

Температура підігріву таких з'єднань при зварюванні повинна вибиратися з термічного режиму 3 розрахунку для 12-відсоткової хромової сталі. Після зварювання необхідно виконати відпуск при в інтервалі $700-750^{\circ} \mathrm{C}$.

У ході термічної обробки слід вживати заходів до прискореного охолодження конструкції, щоб уникнути прояву ефекту крихкості, за температури $475^{\circ} \mathrm{C}$ [10]. Проведення відпуску помітно підвищує корозійну стійкість зварного з'єднання, насамперед у районі навколошовної зони сталей ферито-аустенітного класу, що підтверджено результатами експерименту.

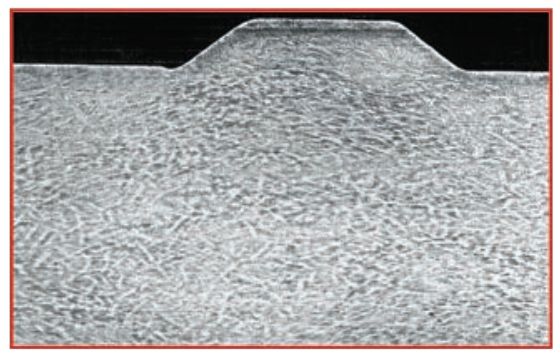

Рис. 1. Вид зварного з'сднання сталі 3 феритною структурою

При зварюванні з'єднання 08X13 + 10ХСНД застосовуються також аустенітні, електродні та присадочні матеріали. Температура підігріву може бути знижена на $100-150^{\circ} \mathrm{C}$, на відміну від необхідного режиму для високохромистих сталей [12].

При проведенні дослідження визначено, що температура підігріву при зварюванні перебувала в межах $130-180^{\circ} \mathrm{C}$. За необхідності викликаної умовами забезпечення необхідного рівня властивостей і стійкості проти міжкристалітної корозії температура термічного відпуску виробу може бути підвищена до $800-850^{\circ} \mathrm{C}$.

Для попередньої оцінки придатності зварювальних матеріалів доцільно використовувати поділ аустенітних сталей по зварюваності на дві групи [13]. До першої з них належать найбільш поширені аустенітні сталі, в яких вміст основного легуючого елемента - хрому - перевищує або близький до вмісту нікелю $>1 \%$. Ці сталі можуть зварюватися найбільш технологічними електродними матеріалами аустенитно-феритного класу. Друга група охоплює стали з підвищеним запасом аустеніту, в яких вміст нікелю перевершує вміст хрому $<1 \%$ і які аустенитно-феритними електродними матеріалами зварюватися не можуть [14].

Вищевказані доводи були ключовими у розробці технології зварювання суднового вузла елемента відцентрового насоса.

На підставі вищевикладеного матеріалу і проведених досліджень була розроблена технологія відновлення працездатності вузла суднової енергетичної установки. Так, на рис. 2 приведена схема кріплення лопаті відцентрового насоса до маточини. Маточина 1 виконана 3 феритної сталі марки 0X13, приварюється до неї лопать 3 , виготовлена 3 маловуглецевої сталі. Зварювальний шов 2 виконаний із кутовим профілем, 
зі збереженням установочного розміру Н. За умовами зварювання для стали 0Х13, так само як і маловуглецевої сталі, підігріву або зовсім не потрібно, або його температура не перевищує $100-150^{\circ} \mathrm{C}$. Такий же термічний режим був прийнятий і при зварюванні комбінованого з'єднання, яке використовувалося в насосі цього типу, електродами типу Е-ХМ. Спочатку заварювався зовнішній кільцевої шов, після чого швом до маточини приварювалася внутрішня сорочка на глибину $h$. При виконанні шва утворювалися кільцеві тріщини, що йдуть переважно поблизу межі сплаву зі сталлю 0Х13.

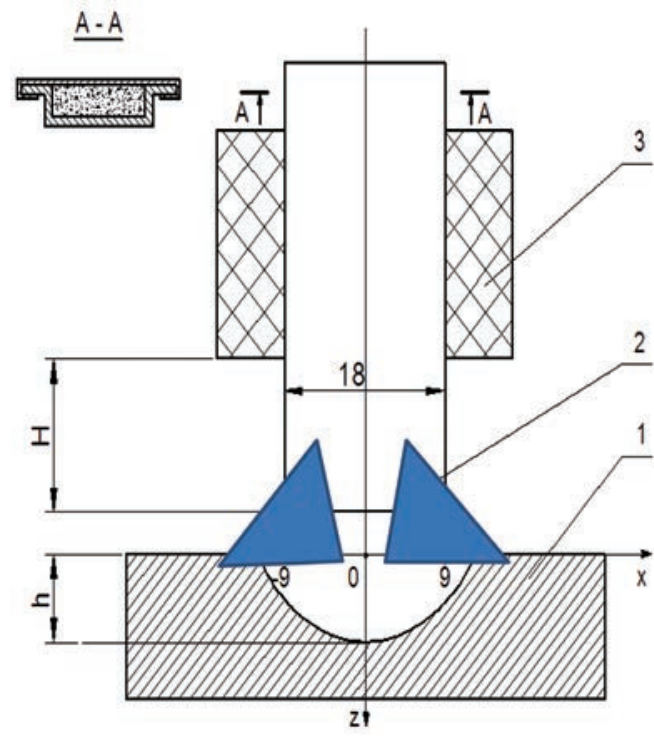

Рис. 2. Схема приварки лопаті відцентрового насоса до маточини

При детальному розгляді вузла, зображеного на рис. 2, були виявлені тріщини, які є наслідком виникнення загартованих ділянок перлітного шва за рахунок проплавлення крайок високохромистої сталі. Щоб уникнути цього дефекту, необхідно ввести підігрів деталей до температури $300-400^{\circ} \mathrm{C}$. Ці дії мінімізують ризики появи тріщин. Особливо слід відзначити ту обставину, що при ремонті суднового відцентрового насоса вимоги до режиму підігріву комбінованого вузла рис. 2 вищі, ніж вимоги до підігріву складників деталей. Тому при використанні електродних і присадних матеріалів аустенітного класу режим підігріву перед зварюванням може бути змінений у бік зниження його температури на $150-200^{\circ} \mathrm{C}$. Це відрізняється від режимів, застосовуваних для однорідних з'єднань [15]. Так, наприклад, після труднощів при виготовленні вузла маточини насоса (рис. 2) вихід був знайдений шляхом заварки вузла аустенітними електродами без підігріву і наступної термічної обробки.

Особливий акцент необхідно зробити на те, що при виготовленні суднових конструкцій найбільш поширені хромо-молібдено-ванадєві сталі марок 12Х1МФ і 15Х1М1Ф. Їх властивості більш стабільні через наявність у них вільних карбідоутворюючих елементів (Cr , Мо і V). Водночас ці сталі при тривалих витримках на температурах вище $500^{\circ} \mathrm{C}$ також схильні до утворення дифузійних шарів у зоні сплаву 3 аустенітним швом. Тому температура їх експлуатації повинна обмежуватися $500^{\circ} \mathrm{C}$.

Дослідження показали що найбільш стабільними перлітний сталями є 5-процентні хромисті стали марок X5, X5M і Х5МФ, а також високо-

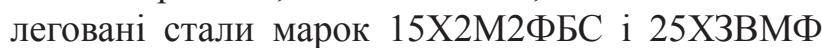
(EN 415). При їх експлуатації для роботи в зоні температур до $550-580^{\circ} \mathrm{C}$ можна не побоюватися помітного розвитку дифузних шарів.

Також на підставі даних проведених досліджень можна відзначити, що гранична температура застосування в різнорідних зварних з'єднаннях частки перлітної складової частини може бути підвищена:

а) при введенні перехідників із перлітної сталі з більш високим вмістом у них активних карбідоутворюючих елементів;

б) використання захисних облицювальних перлітових наплавлень на кромки перлітної стали,
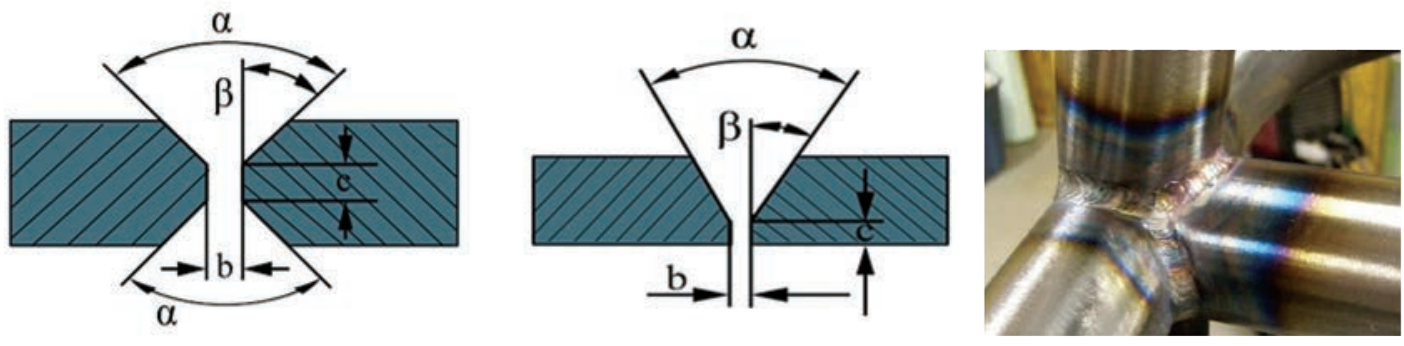

Рис. 3. Схеми розділок під зварювання з обробленими перлітними крайками: a - X-подібне оброблення; б - V-подібне оброблення; в - зварне з'сднання труб із розширеним кордоном сплаву 

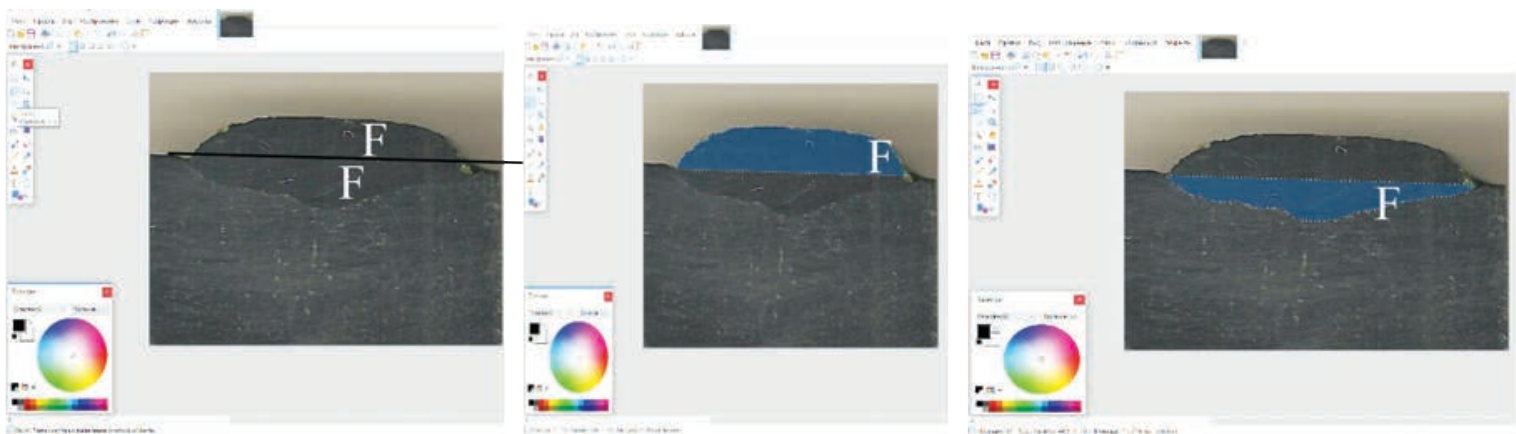

Рис. 4. Визначення частки участі основного металу в наплавленому за допомогою програми: a - зображення зразка; б - сектор площі наплавлення; в - сектор площі проплавлення

облицювальний шар повинен мати більший вміст активних карбідоутворюючих елементів, ніж перлітний основний метал.

Вставки-перехідники зі стабільних перлітових сталей найбільш доцільно застосовувати у стиках трубопроводів (рис. 3). 3'ясовано, що важливими для підготовки під зварювання $є$ геометричні розміри (рис. 3 ) стиків: $\alpha, \beta$ - кути розділу основного металу, b, c - зазор і притуплення металу. Слід звернути увагу на те, що облицювання кромок зварювальних у з'єднаннях різнорідних сталей (рис. 3), крім зменшення інтенсивності дифузійних шарів, може використовуватися також для усунення підігріву при зварюванні, а також зменшення небезпеки утворення тріщин при зварюванні конструкцій підвищеної жорсткості зі сталями, схильними до гартування [16].

Результати вимірів визначили товщину облицювального шару при зварюванні незагартованих сталей у межах 5-6 мм. У випадках застосування сталей, схильних до гартування, товщина облицювального шару повинна бути збільшена до 9 мм. Метал облицювання не може бути піддано загартуванню при зварюванні. Схема обробки крайок зварного шва після нанесення облицювання може бути обрана за аналогією до стикового зварного з'єднання.

У дослідженні застосовувалася програма Lasso і здійснювалося виділення кордонів шва - проплавления $\left(\mathrm{F}_{\text {пр }}\right)$ і наплавлення $\left(\mathrm{F}_{\text {н }}\right)$. Програма автоматично прораховувала площу у квадратних пікселях, підставляючи ці значення у вираз
$m=F_{n p} \cdot 100 \% /\left(F_{n p}+F_{n}\right)$, і ми отримували значення частки участі основного металу в наплавленому (рис. 4).

Визначено вплив легуючих елементів при зварюванні плавленням на частку основного металу у шві. Відсоток основного наплавленого металу склав інтервал близько 56-60\%, а залишок обсягу 40-43\% - структура легуючих елементів і перехідні структури металу шва.

Висновки. У ході дослідження й аналізу експлуатаційних властивостей матеріалів, застосовуваних за суднових умов, визначено максимальне рекомендоване значення робочої температури для вуглецевих і хромо-молібденових сталей із вмістом $\mathrm{Cr} 1 \%$ і Мо $1 \%$ на рівні $500^{\circ} \mathrm{C}$.

Визначено, що за температури експлуатації суднових конструкцій в інтервалі $450-500^{\circ} \mathrm{C}$ не виникає розвитку дифузійних шарів в у сплаву хромо-молібденової сталі зі швом. Обгрунтовано, що ці умови експлуатації є оптимальними для сталей такого класу.

Визначено співвідношення пропорцій зварного шва і легуючих елементів при зварюванні плавленням на частку основного металу. Відсоток основного металу - $60 \%$, а залишок обсягу $40 \%$ - структура легуючих елементів і перехідні структури шва.

Сформульовано основні напрями впроваджень результатів проведеного дослідження. Розроблено технологію виготовлення і ремонту вузлів суднових енергетичних установок із застосуванням низьколегованих сталей і проаналізованих видів термічної обробки.

\section{Список літератури:}

1. Chigarev V.V., Belik A.G. Flux-cored strips for surfacing. Welding International. V. 26. P. 975-979. 2012.

2. Фока А.А. Судовой механик. 2010. Одесса, Феникс, Т.1. 1030 с.

3. Kovalenko I., Spiridonov V. Operation reliability evolution of the ship power pipelines with application of mathematical modeling and ultrasonic testing methods. The scientific heritage. V. 6. P. 88-91. 2016.

4. Chigarev V.V., Belik A.G., Zarechenskii D.A. Optimization of the fractional composition and performance melting powder tapes with exothermic mixture in the filler. Welding International. V. 30. № 7. P. 557-559. 2016. 
5. Чигарев В.В., Коваленко И.В. Способ увеличения срока службы металлургического оборудования. Вестник ПГТУ. № 20. С. 231. 2010.

6. Чигарев В.В., Коваленко И.В. Исследование эксплуатационных свойств биметаллических сварных соединений. Вестник ПГТУ. № 22. С. 161. 2011.

7. Готальский Ю.Н. Сварные соединения разнородных сталей. Москва : Техника, 1981. 185 с.

8. Патон Б.Е., Чепурной А.Д., Саенко В.Я. и др. Перспективы производства толстостенных биметаллических корпусов высокого давления. Автомат. сварка. № 1. С. 30. 2004.

9. Закс И.А. Сварка разнородных сталей. Москва : Статус - Эко, 1973. 208 с.

10. Махненко В.И. Ресурс безопасной эксплуатации сварных соединений и узлов современных конструкций. Киев : Наукова думка, 2006. 618 с.

11. Патон Б.Е., Медовар Л.Б., Саенко В.Е. Новые возможности автоматической сварки в машиностроении. Металлургия машиностроения. № 1. С. 2. 2003.

12. Медовар Б.И. Сварка хромоникелевых аустенитных сталей. Москва : Машгиз, 1958. 258 с.

13. Mohammad Essa Ahmad, Chigarev W.W., Belik A.G. Application of flux-cored strips for ruggedization and reconditioning of machine parts. Modern Developments in Renewable Energy and Sustainabiliti. Kuala Lumpur, Malaysia. P. 110. 2008.

14. Стафаков Ю.П., Побаль И.Л., Князева А.Г. Рост трещин вблизи границы раздела разнородных материалов в условиях сжатия. Физ. мезомеханика. № 1. С. 81. 2002.

15. Харин В.М. Судовые машинные установки устройства и системы. Одесса : Фенікс, 2010. 648 с.

16. Muller E. Geschweisste Turbinenlaufer. BBC. Nachr. Shweissenund Schneiden.1995. V. 47. № 6. P. 277.

\section{Kovalenko I.V. WAYS TO INCREASE TECHNOLOGICAL RELIABILITY OF SHIP ENERGY INSTALLATIONS WITH THE USE OF DIFFERENT STEEL}

At the present stage of development of shipbuilding in the world and in Ukraine, attention is paid to the use of economically alloyed structural materials that have stable performance properties. When developing new technologies used in the manufacture of ship auxiliary mechanisms, it is very important to study the properties of joints of dissimilar steels and the pronounced chemical, structural and mechanical inhomogeneity formed by them. When conducting the analysis of these factors, both the properties and purpose of the construction materials and the choice of its manufacturing technology must be taken into account.

The welding methods used in the development of this technology should minimize costs and optimize the geometry of the weld. Another important factor is the assessment of the degree of alloying of welding steel grades and the level of the total cost of manufacturing the product. Studies of the properties of the transition layers of the weld and the base metal and their effect on the number of load cycles in the tests are also key. Therefore, minimizing the number of diffusion layers in the alloy zone reduces the cyclic fatigue of the weld metal is a major factor.

It is important to compare welded joints of different degrees and classes of alloying. For example, the comparison of thermally strengthened and dispersed hard austenitic steels. For steels of this class, heat treatment after welding is mandatory to restore the properties of the seam area. Also important is the final structure of the seam, which directly determines the number of cycles before the first stage of destruction. In this case, the best properties in terms of operation in fine austenitic and pearlitic structures. A special role is given to the choice of heat treatment modes of the welded joint, it depends on the level of doping of $\mathrm{Ni}, \mathrm{Mg}, \mathrm{Cr}$ as the base metal and the welded joint. It is also necessary to consider the magnitude of operating loads on ship power plants.

Key words: alloying elements, austenite, base metal, weld metal, transition layer, metal structure. 